\title{
Improvement of the production system functioning with using quality management tools in the metallurgical enterprise
}

\author{
Marta Daroń $^{1, *}$, Monika Górska ${ }^{2}$, and Anna Dunay ${ }^{3}$ \\ ${ }^{1}$ Czestochowa University of Technology, Faculty of Management \\ ${ }^{2}$ Czestochowa University of Technology, Faculty of Production Engineering \\ and Materials Technology \\ ${ }^{3}$ Szent István University, Faculty of Economics and Social Science
}

\begin{abstract}
Quality management tools undoubtedly influence the production processes in the company, by the creation of favorable conditions for its improvement. The proper selection and proper use of these tools is essential to improve the functioning of the company. Therefore, the main goal undertaken at work was to assess the situation related to the selection and effectiveness of methods used by a selected company operating in the metal industry. Moreover, it was necessary to determine to what extent these methods are applied and which of them have the greatest impact on the effectiveness of the process of improving the functioning of the enterprise.
\end{abstract}

Key words : improvement, processes, production

\section{Introduction}

The metallurgical industry includes the production of pig iron, ferroalloys, iron, steel, steel products and the production of metal finished products (see Regulation of the Council of December 24, 2007 regarding the Polish Classification of Activities - PKD [1]). Thus, a specific product is created which constitutes the effect of the activities of entities in this industry. Its quality largely results from the functioning of the production system being at the same time the showcase of the company on the market.

Metal industry companies must pay attention to the efficiency and effectiveness of production processes. The most important goals of improving production efficiency include [2]: increase in productivity, improvement in the quality of manufactured products, reduction in the level of work in progress, shortening the time or number of retoolings, shortening production cycles, reducing the need for production space. In order to achieve these goals, the entities of the metal industry have at their disposal many methods or tools of quality management [3], which are described in the next part of the study. The application of them allows introducing improvement actions dedicated to a given production system. However, not all methods may contribute to achieve the same effect. Therefore, the research goal of the work was to analyze the applied methods of production

* Corresponding author: marta.daron@wz.pcz.pl 
system improving in a selected company in the metallurgical industry. There were also presented results of implementing of these methods. Additionally, there was indicated the validity of the applied methods and there was assessed their suitability.

\section{Improving production processes}

The basis for improving the company's production system is the optimal set and use of production factors, which result from the need to meet all customer requirements and adaptation to changing environmental conditions, as well as increase of competitiveness and cost pressure, or increase of the role of internal and external flexibility. The goal of the undertaken activities is to achieve measurable economic and production effects such as the efficiency of the production process and timely performance of tasks, as well as identification of factors that affect not only the quality of products but also shortening of inter-operative times, minimization of inventory. An important role in the improvement of existing production systems or their redesign is mainly played by modern methods of organization and management of production processes that result from the desire to improve efficiency and reduce costs [4].

Process management is embedded into the activities of today's enterprises not only in the field of manufacturing. However, in order to be able to talk about process management, one should realize the necessity of measuring it - to evaluate its efficiency, flexibility, etc. Numerous process measures are indicated in the literature [5-7]. Some of them can be used in general, but there are also those dedicated to specific processes (production, logistics, customer service and others). Nevertheless, each process should be assessed by measuring the main attributes of the process [8]: process costs, length of process completion time, flexibility, quality, organization relevance, customer relevance and the ethical dimension of the process. What's more, there are a number of methods and tools described in the literature that are useful by improving each process, e.g. TQM, 5WHY, Pareto chart, the control chart, the Ishikawa diagram, the relationship diagram, process mapping, ABCD (Audience, Behavior, Condition and Degree Method - which is an expert tool that allows to identify the most important causes of the problem, according to the evaluators) and others. However, there are also those that are used to analyze individual categories of processes, e.g. production: FMEA (Failure Mode and Effects Analysis), SMED (Single Minute Exchange of Die), TPM (Total Productive Maintenance), Poka Yoke, 5W2H method or 5S [9-13]. Assessment of a given process is often the basis for undertaking actions aimed at introducing improvement changes.

\section{Main results}

The presented research was carried out in a metal industry enterprise belonging to mediumsized business entities (according to the employment size criterion in accordance with the European Commission Regulation No. 364 of February 25, 2004 on SME [14]). The main production profile are rolling logs and other metal elements sold on the domestic and foreign market. The selection of the company for the study was partly random - related to the selection of the unit from the manufacturing industry, and partly deliberate - related to the knowledge of the industry and location-related, which involved the possibility of conducting direct research. The surveyed company plans to expand its activity, therefore the problem of process improvement is inscribed in its development strategy.

To achieve research goal, a direct survey was conducted in a selected company, covering the last four years (due to the low percentage of people working in the surveyed enterprise over 5 years). Respondents were employees of the production department and 
their superiors, engaged in key processes (production). The research tool was a questionnaire consisting of open, semi-open and closed questions. On the basis of the analysis of the answers from open and semi-open questions, some groups of answers were created (this concerned mainly the indication of the benefits from the implementation of specific improvement instruments). Some of the questions also made it possible to assess research feature in the form of a rank (from the least important to the most important / from useless to the most useful, etc.). Parallel, a direct interview was conducted with persons on managerial positions, in which the improvement activities undertaken within the field of production were analyzed over four years. On the basis of company's data from the selected research period there was also analyzed the level of selected indicators (production readiness of machines, their efficiency and production involvement). This made it possible to identify specific measurable benefits in the area of production.

First of all, the knowledge of the respondents regarding the methods and techniques of improvement of processes used in the surveyed enterprise was assessed. Then, the respondents were asked to indicate which of these instruments are used by them in practice (Fig. 1).

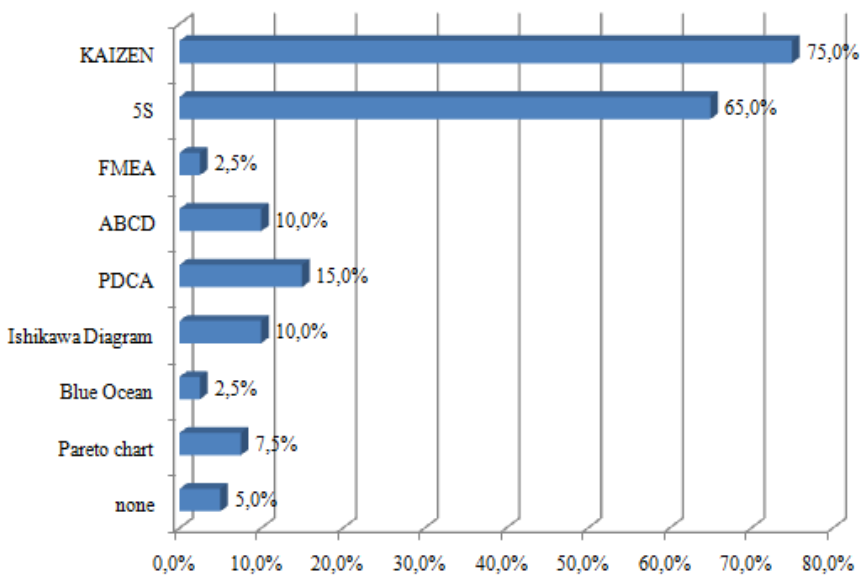

Fig. 1. Improvement instruments used in practice by respondents in a selected company.

The results of the study confirm that, from among many available methods in the process of improving the processing system, in practice, two are mainly used, i.e.: Kaizen and $5 \mathrm{~S}$. Only $5 \%$ of respondents ( 2 production employees) stated that they did not use any improvement instruments.

According to Grajewski's research on the use of tools for improving processes [7] there is shown that in many cases the methods are misused or have a low level of suitability. Therefore, it was reasonable to test the level of suitability of the methods used in the research entity in the respondents' opinion. Due to the experience and practical knowledge of the respondents participating in the study, their assessment of the level of usefulness of methods and improvement tools is correct in substance. The results of the study on determining the level of suitability of selected improvement instruments in processing processes are presented in Table 1.

Analyzing the results from Table 1, the surveyed employees consider the $5 \mathrm{~S}$ method as the most useful improvement technique for the company. As many as $45 \%$ of respondents awarded "7" in this case. In turn, $47 \%$ of respondents consider the Kaizen technique (score 6) to be important in this respect. On the other hand, 35\% of respondents considered the FMEA method (assessment 5) to be helpful in improving their activities. In the case of the analyzed method, the obtained result proved that despite the using of this tool in practice by 
only one person, other employees had knowledge about it. Although they did not use this method, they participated in the development of relevant data, which was a key source of information for FMEA process analysis. The decisions that were made on the basis of FMEA were disseminated among the employees of the processing area, which was reflected in the research results.

Table 1. Assessment of the usefulness of improvement tools [\% of respondents].

\begin{tabular}{|c|c|c|c|c|c|c|c|}
\hline \multirow[t]{2}{*}{ Improvement tools } & \multicolumn{7}{|c|}{$\begin{array}{c}\text { Assessment } \\
\text { (Grade } 1 \text { - unhelpful tool / method of improvement, } \\
\text { assessment } 7 \text { - improvement tool useful in the highest } \\
\text { degree) }\end{array}$} \\
\hline & 1 & 2 & 3 & 4 & 5 & 6 & 7 \\
\hline Kaizen & 0 & 0 & 5 & 5 & 20 & 47 & 23 \\
\hline $5 \mathrm{~S}$ & 7 & 4 & 4 & 7 & 13 & 20 & 45 \\
\hline FMEA & 0 & 7 & 15 & 25 & 35 & 13 & 5 \\
\hline PDCA & 0 & 7 & 18 & 33 & 22 & 15 & 5 \\
\hline $\mathrm{ABCD}$ & 18 & 20 & 33 & 12 & 5 & 5 & 7 \\
\hline Ishikawa Diagram & 30 & 40 & 15 & 10 & 0 & 0 & 5 \\
\hline Pareto Diagram & 45 & 22 & 10 & 8 & 5 & 0 & 10 \\
\hline
\end{tabular}

The analysis of the remaining results of the study shows that the respondents positively assess the effectiveness of tools and techniques used in the enterprise. As many as $80 \%$ of employees believe that information received using selected methods or techniques were helpful by identifying and improving those areas that should be subjected to improvement processes. In the examined case, the area that needed changes the most over the period (i.e. four years), was the area of production including such elements as: the technology used, machines, equipment and technical equipment. Therefore, the company invested financial resources in the modernization and extension of the machine park. As a result of the actions taken, there were eliminated some of the reasons that were responsible for the quality deficiencies of the finished product resulting from the use of outdated production technology. The largest amount of financial capital was invested in machinery and technical equipment, which resulted in not only improving the quality of the production process itself, but also the finished product. Currently, the company has one of the latest technological lines for the production of bearings. Confirmation of the legitimacy of introducing improvement actions was reflected in the growth of indicators, i.e.: production readiness of machines (machines installed / machines owned * 100\%), machines' efficiency (active machines on the largest change / machines owned * 100\%) and production commitment (active machines on the largest change / machines installed * 100\%). The indicators' increase is the preferred situation. The analysis of collected data allows to state that the indicator of production readiness of machines and devices remains constant, i.e. $100 \%$. Index of machine and equipment efficiency from $68.84 \%$, in 2014 increased to the level of $92.68 \%$ in 2017 . The index of production engagement of machines and devices oscillated in similar limits as the index of machines and devices efficiency. The machine and equipment efficiency index improved as a result of the modernization of the machine park. It is also important to increase the skills of employees in the field of management and control of machines and devices. The above means that improvement actions have had a positive effect

Undoubtedly, every enterprise striving to improve its operations and to match more completly to the market needs should undergo a detailed analysis of the benefits resulting 
from the introduction of improvement actions using appropriate instruments. Therefore, the issue was analyzed in the next stage of the study (Table 2).

Table 2. Benefits from the implementation of improvement tools [\% of respondents].

\begin{tabular}{|c|c|c|c|c|c|c|c|}
\hline \multirow[t]{2}{*}{ Advantages } & \multicolumn{7}{|c|}{$\begin{array}{c}\text { Assessment } \\
\text { (Grade } 1 \text { - no benefits, grade } 7 \text { - the occurrence of a } \\
\text { given benefit to a very appreciable extent) }\end{array}$} \\
\hline & 1 & 2 & 3 & 4 & 5 & 6 & 7 \\
\hline $\begin{array}{l}\text { Improving efficiency and } \\
\text { modernization of the } \\
\text { production process }\end{array}$ & 10 & 17 & 33 & 20 & 13 & 7 & 0 \\
\hline $\begin{array}{l}\text { Increased demand for } \\
\text { offered products }\end{array}$ & 40 & 23 & 25 & 7 & 5 & 0 & 0 \\
\hline $\begin{array}{l}\text { Improvement of quality, } \\
\text { including work safety }\end{array}$ & 25 & 46 & 13 & 5 & 8 & 0 & 3 \\
\hline $\begin{array}{l}\text { Improving the control of } \\
\text { the production process }\end{array}$ & 5 & 0 & 5 & 8 & 17 & 25 & 40 \\
\hline $\begin{array}{l}\text { Increased competence and } \\
\text { responsibility of } \\
\text { employees }\end{array}$ & 5 & 3 & 7 & 10 & 10 & 38 & 27 \\
\hline $\begin{array}{l}\text { Increased competitiveness } \\
\text { of products }\end{array}$ & 10 & 11 & 17 & 32 & 15 & 10 & 5 \\
\hline $\begin{array}{l}\text { Organization of } \\
\text { documentation }\end{array}$ & 5 & 0 & 0 & 18 & 32 & 20 & 25 \\
\hline
\end{tabular}

The analysis of the results contained in Table 2, allows to conclude that the benefits that result from the implementation of improvement tools and techniques, the respondents mainly consider improving the control of the production process. As many as $40 \%$ of respondents chose the indicator "7" in this case. Undoubtedly, streamlining the control of the production process is essential in a properly operating company. Wrongly, the respondents assess very high the benefits of increasing the demand for offered products. The least important factor was indicated by $46 \%$ of respondents. Increasing demand means the necessity to increase production and increase profits for the company. $33 \%$ of the respondents rated increasing the efficiency and modernization of the production process on 3 on a seven-point scale. This is partially explained by the recently introduced technological changes in the surveyed enterprise. However, improving the efficiency of processes should be continuous, therefore emphasis should be placed on the greater involvement of employees in this area. Respondents paid little attention to improving work safety, by this indicator "2" was marked by $46 \%$ of respondents.

\section{Summary}

The selection of appropriate methods and tools is of fundamental importance in the improvement process. They are used to collect and process information, supervise processes, detect errors and defects, finally allowing to check the effectiveness of decisions made. They are therefore necessary for the proper functioning of the enterprise.

The research (case study) concerned the production system of a selected company in the metallurgical industry. It is obvious that each entity should have its own set of improvement tools. However, the results obtained allowed to draw specific conclusions and shed light on further research directions. The presented methodology can be successfully applied in other production units. It would be reasonable to extend this type of research to a larger group of entities in a given industry. Perhaps it would be possible to create a model for the selection 
of specific methods / tools, also in the context of specific benefits from application of them, which would be dedicated to enterprises in a given industry. The obtained results of the research allowed to determine which of the tools are the most popular in the studied enterprise and at the same time which and to what extent they allow to achieve specific benefits. The analysis of the respondents' answers also showed that the improvement tools used do not always allow achieving the assumed benefits (they are not always useful or do not correspond to the expected benefits).

The results are presented as a whole for the research sample. For a more in-depth analysis, it should be presented in a breakdown into groups of employees (production and their superiors). For example, production workers evaluated different methods, whereas they actually used only 2 (5S and Kaizen), while their superiors used much more improvement methods at work which was combined with the specificity of their work analysis and evaluation of processes, etc. Unfortunately, the volumetric framework of this study does not allow to present such a detailed analysis.

\section{References:}

1. Rozporządzenie Rady Ministrów z dnia 24.12.2007 r. w sprawie Polskiej Klasyfikacji Działalności - PKD, Dz. U. z 2007 r. nr 251, poz. 1885 z późn. zm.

2. A. Koliński, Log., 5, 1083-1091 (2011)

3. R. Ulewicz, Manuf. Tech., 14, 104-111 (2014)

4. M. Brzeziński, Organizacja produkcji w przedsiębiorstwie (Difin, Warszawa, 2013)

5. M. Flieger, Przeg. Org., 9, 38-42 (2009)

6. K. Bors, B. Nogalski, Strategie wzrostu produktywności firmy (Akad. Ek. w Krak., Kraków, 2000)

7. S. Suss, V. Thomson, J. Eng. Des., 23, 829-851 (2012)

8. P. Grajewski, Organizacja procesowa (Pol. Wyd. Ek. S.A., Warszawa, 2016)

9. B. Cs. Illés, Cs. Szuda, (A. Dunay (ed.) Proceedings of the 5th International Conference on Management 2015: Management, Leadership and Strategy for SMEs' Competitiveness, (Szent István Publ. H., Gödöllő, Hungary, 2015)

10. B. Cs. Ilés, Cs. Szuda, A.Dunay, (B. Cs. Illés, M. Nowicka-Skowron, E. Horská, A. Dunay, (eds.) Management and Organization: Concepts, Tools and Applications, (Pear. Ed. Ltd Harlow UK, 2017),

11. S. Kot, K. Grondys, Applied Mechanics and Materials, 309, 324-331 (2013)

12. N. Baskiewicz, M. Kadłubek, Prace Naukowe UE we Wrocławiu, 463, 121-131 (2017)

13. K. Nowakowska, M. Ingaldi, Archiwum Wiedzy inżynierskiej, 1(1), 39-41 (2016)

14. Rozporządzenie Komisji (WE) nr 364/2004 z dnia 25 lutego 2004r. o MSP, Dz. U. UE 28.2.2004 